\title{
As mulheres só querem ser salvas: Sex and the City e o pós-feminismo
}

\author{
Márcia Rejane Messa ${ }^{1}$ \\ msmessa@terra.com.br
}

\begin{abstract}
Resumo: Diante da ainda tímida atenção acadêmica à ficção seriada, especialmente à sitcom, apresento neste artigo os resultados de minha dissertação, defendida em dezembro de 2006, que utiliza como ferramenta o circuito de cultura de Richard Johnson para entender a sitcom norteamericana Sex and the City. De forma sucinta, tento aqui esboçar meu percurso metodológico a fim de demonstrar como utilizei o circuito cultural desenvolvido por Richard Johnson para refletir acerca da representação da mulher e da "solteirice" no programa em questão, assim como questionar sua conexão com o que vem sendo chamado de pós-feminismo.
\end{abstract}

Palavras-Chave: pós-feminismo, consumo cultural, Sex and the City

Abstract: In the face of a lack of significant academic attention to serial fiction, especially to sitcoms, I present in this article the results of my dissertation, which I defended in December, 2006. I used, for my analyses, Richard Johnson's circuit of culture as a tool to understand the North American sitcom Sex and the City. In this article, I try to briefly present my methodological pathway, in order to demonstrate how I used the circuit of culture developed by Johnson to reflect the representation of women and of being single in the show, as well as to question its connection with what is now being called post-feminism.

Keywords: post-feminism, cultural consumption, Sex and the City

Resumen: Ante la aún tímida atención académica a la ficción de las series de televisión, especialmente las de sitcom, presento en este artículo los resultados de mi tesina, defendida en diciembre de 2006, la cual utiliza como herramienta el circuito cultural de Richard Johnson, para comprender la sitcom norteamericana Sex and the City. De forma sucinta, intento esbozar mi evolución metodológica en esta investigación, a fin de enseñar como he utilizado este circuito cultural, desarrollado por Johnson, para reflexionar acerca de la representación de la mujer y de la soltería en este programa, así como cuestionar su conexión con lo que se viene llamando de posfeminismo.

Palabras Clave: posfeminismo, consumo cultural, Sex and the City.

1 Mestre em Comunicação pelo Programa de Pós-Graduação em Comunicação da Famecos/PUCRS. Este artigo apresenta o resultado da dissertação As mulheres só querem ser salvas: Sex and the City e o Pós-feminismo, realizada com o apoio do CNPq. E-mail: msmessa@terra.com.br 
Décadas depois das mulheres terem sido as agentes de um movimento que deu partida em mudanças irreversíveis - embora ainda esparsas - para a evolução do feminino, muitas ainda enfrentam em suas rotinas situações paradoxais. A inserção no mercado de trabalho e na universidade, por exemplo, surtiu efeitos em suas vidas afetivas. Segundo matéria da Revista Veja especial Mulher, as brasileiras têm mais anos de estudo que os homens e estão mais aptas a obterem carreiras de prestígio, entretanto, este fato estimula a "solteirice": "Se isso ajuda profissionalmente - triste ironia -, pode também atrapalhar sentimentalmente" (SEKEFF, 2006).

Diante de paradoxos como este, com os quais nos deparamos a todo instante através da mídia e de nossas interações sociais, propomos aqui voltar nosso olhar a uma produção norte-americana que obteve grande repercussão no Brasil e que tematiza questões como a descrita acima, onde o feminino é exposto constantemente a contradições, questionamentos e momentos de instabilidade.

O programa em questão é a sitcom Sex and the City (1998-2004) 2, que teve seis temporadas (todas disponíveis em DVD), um total de 94 episódios, cerca de 45 horas de programa (cada episódio tinha, em média, 25 minutos), e trazia a história de quatro mulheres solteiras, bonitas, inteligentes, independentes, sexualmente ativas e com idades entre 30 e 40 anos. Em Sex and the City (STC a partir de então), as representações femininas eram construídas de forma estereotipada (como toda sitcom) e as personagens tinham anseios e características que, no senso comum, são típicas do imaginário feminino.

A pesquisa desenvolvida teve o propósito de investigar quem era a mulher representada em STC e como a espectadora brasileira interpretou, reproduziu e/ou resistiu às representações da feminilidade e masculinidade veiculadas pelo programa. Os objetivos gerais foram desenvolver um estudo cultural crítico que contemplasse o circuito de cultura proposto por Richard Johnson (basicamente composto pela produção, texto e recepção) e produzir uma análise que contribuísse para uma melhor compreensão da situação da mulher na sociedade contemporânea, assim

\footnotetext{
${ }^{2}$ No Brasil o programa foi ao ar de 2002 a 2004 inicialmente pela $\mathrm{HBO}$ e, mais tarde, pelo Multishow. Este último exibe atualmente uma versão com cortes do programa, sem cenas de sexo, recebendo, por esta razão, o nome Sex and the City Light.
} 
como levantar questões pertinentes acerca do papel que a cultura da mídia tem neste contexto, com especial atenção ao panorama brasileiro.

O circuito cultural de Richard Johnson (2004) está aqui assumido como uma ferramenta de análise para produtos culturais que assumem formas de mercadorias capitalistas. Neste, o material bruto "texto" (aqui STC) não deve ser analisado desvinculado de sua produção e recepção sob o risco de não dar conta de toda sua complexidade. Ao propor o circuito de produção, circulação e consumo de produtos culturais, Johnson argumenta que existem três modelos principais de pesquisas em Estudos Culturais: aqueles centrados na produção, os centrados no texto e outros baseados na recepção. O autor indica, em contraponto a esta divisão, que o desenvolvimento de uma compreensão do mecanismo de produção e circulação de produtos culturais tem maiores chances de se efetivar se percebermos as diferentes articulações entre estes três momentos. Cada um deles (produção, texto e recepção) é uma engrenagem indispensável ao funcionamento e entendimento do todo e, apesar de distintos, estes momentos são completamente dependentes um do outro: "quero sugerir que, nas condições sociais modernas, esses processos são intrínsecos aos circuitos culturais e que eles são produzidos por relações de poder, ao mesmo tempo que as produzem" (JOHNSON, 2004, p.41).

\section{A produção de Sex and the City}

O momento da produção é, segundo Hall (2003), aquele onde o circuito começa e a construção da mensagem se dá a partir de referenciais estabelecidos pelos produtores. O meio, assim como sua estrutura são, neste processo, também fornecedores de mensagens codificadas que estarão impressos no texto que chega ao receptor. É o momento da produção que sinaliza as formas de produzir que irão afetar o produto final (HALL, 2003).

Para compormos o âmbito da produção de STC fizemos um levantamento bibliográfico em websites, revistas, livros autorizados 3 ou não pela $\mathrm{HBO}$ sobre a sitcom, programas televisivos e jornais da época 4 . Nosso interesse foi tanto nas

3 O único livro autorizado pela $\mathrm{HBO}$, de onde tiramos grande parte das entrevistas com as atrizes, roteiristas e criadores, é o Sex and the City Kiss and Tell (2003).

4 De 1998, quando iniciou nos Estados Unidos, até 2004, quando teve seu final exibido no Brasil. 
entrevistas dos criadores do programa, quanto das protagonistas, além das matérias e artigos acerca de seu lançamento e repercussão. Na medida do possível, buscamos estas informações em seu contexto de origem, mas o que foi publicado no Brasil também foi avaliado. Por esta razão, realizamos uma entrevista com a jornalista brasileira Teté Ribeiro, autora de um livro sobre a sitcom.

É importante assinalar como vemos STC. Em nossa concepção, trata-se de uma comédia de situação (sitcom) sobre mulheres solteiras que traz sempre quatro pontos de vistas sobre uma mesma questão. Sua estrutura assemelha-se à crônica literária, uma vez que trata de assuntos corriqueiros da sociedade de uma forma aparentemente superficial e cômica (CASEY et. al, 2002). Nos Estados Unidos, até o final dos anos 90, grande parte das sitcoms era encenada em estúdio, incorporando as risadas do público ao programa final que ia ao ar. Atualmente, isso não é mais uma prerrogativa, pois muitas sitcoms trazem tomadas externas e dispensam as "risadas" como uma maneira de engajamento. Esta sensação, nas sitcoms de hoje, se dá cada vez mais pela verossimilhança, pela inserção do cotidiano na narrativa.

A verossimilhança, ao contrário do realismo - que é um termo problemático por ser a realidade sempre construída pela ficção -, se refere não necessariamente ao que reconhecemos como parte do mundo, mas ao que a cultura dominante em que estamos inseridos acredita que é o mundo, o que é geralmente aceito e crível (GLEDHILL, 1997). Logo, há uma diferença entre verossimilhança cultural e genérica. Ao ser reconhecido como uma sitcom, STC obedeceu aos critérios deste tipo de produção, às convenções do gênero. A verossimilhança genérica permite brincar com a fantasia dentro da credibilidade genérica oferecida pelo programa (por exemplo, Carrie sair flutuando depois de um encontro bem sucedido com um pretendente, indicando que estava feliz, "nas nuvens")5, enquanto que a verossimilhança cultural se refere às normas e ao senso comum da vida social fora da ficção (GLEDHILL, 1997), ou seja, ainda usando como referente o mesmo episódio, à noção de sentimentalismo feminino, que as mulheres dão grande valor e se envolvem rapidamente com homens sedutores, que as cortejam e tratam bem.

\footnotetext{
5 Ep. 5, da $1^{\text {a }}$ temporada. Este episódio foi analisado em profundidade na dissertação. Por motivos de espaço, toda a análise dos episódios foi descartada deste artigo.
} 
A idéia de produzir um programa sobre mulheres solteiras em Nova York surgiu em 1996, quando Darren Star conheceu Candace Bushnell, que escrevia uma coluna intitulada Sex and the City para o New York Observer, um jornal focado na cultura de Manhattan e direcionado aos ricos e poderosos que nela habitavam. Nesta coluna, Bushnell relatava e ironizava as experiências amorosas de modelos e solteiros cobiçados de Manthattan através de seu alter-ego, Carrie Bradshaw. Star e Bushnell se tornaram amigos e começaram a discutir a possibilidade de criar uma série baseada na coluna da escritora. Para Star, o que realmente chamava a atenção era a idéia de uma mulher solteira de seus 30 anos escrever sobre relacionamentos e fazer disso uma ferramenta de auto-conhecimento.

A HBO, canal de televisão a cabo que colocou em prática o projeto STC, foi criada em 1972 e pioneira em novas formas de distribuição via satélite nos Estados Unidos. De propriedade privada, sem nenhum tipo de ligação governamental, a HBO é um canal que se preocupa constantemente com programas originais e direcionados a diferentes públicos. Abordar temas como o sexo, sem cortes, por exemplo, é uma marca registrada do canal.

Segundo Michael Patrick King (apud SOHN, 2002), escritor e produtor executivo do programa, a busca de Carrie - personagem principal da sitcom - pelo homem certo foi sempre a linha central de STC. Ao contrário das heroínas tradicionais, Carrie não vê o casamento como o final de uma jornada e é esta tensão que torna sua personagem tão ambivalente. Sarah Jessica Parker declara, ao falar sobre sua personagem, que a considera bastante "antiquada": "se não o fosse, ela não estaria nesta busca interminável" (PARKER apud SOHN, 2002, p. 22). Segundo ela, todas as personagens colheram os benefícios do movimento feminino, pois demonstram sua liberdade sexual, senso de oportunidade e a habilidade para o sucesso: "se você já cresce com o direito de escolher, votar, se vestir como bem entender, dormir com quem quiser e ter o tipo de amizade que deseja, isto é o que a constitui enquanto mulher" (PARKER apud SOHN, 2002, p. 24).

Entretanto, a atriz diz que o programa não tem uma proposta feminista ${ }^{6}$, uma vez que, se assim o fosse, as feministas “de verdade” iriam questionar aquelas

\footnotetext{
${ }^{6}$ Durante as seis temporadas há apenas uma menção explícita ao movimento feminista/feminismo, quando Charlotte decide que largará seu trabalho para se dedicar ao
} 
mulheres e querer que algumas coisas fossem diferentes para elas. Esta não é só sua opinião. Suas parceiras de elenco também vêem desta forma, embora não cheguem a fazer, em nenhum momento, qualquer menção ao feminismo. Cynthia Nixon (Miranda) diz que o programa mostra o quanto as amizades são importantes quando você não é casada e não tem uma família:

O programa fez a 'solteirice' parecer mais divertida. Acabem ou não estas mulheres casadas, o casamento não é a única medida de suas vidas. Há momentos em que STC faz com que você tenha muito orgulho de ser uma mulher ou estar solteira, em outros momentos, entretanto, faz com que você se sinta muito triste por estas duas coisas. (NIXON apud SOHN, 2002, p. 86)

Kim Cattrall (Samantha) aponta que as mulheres sexualmente livres ou "promíscuas" sempre foram punidas através dos tempos, sendo sempre mortas ou abusadas. STC, segundo Cattrall, "tornou possível para a mulher falar a respeito do que ela gosta ou não sexualmente. Levantou a bandeira da honestidade. Eu acredito que STC é sobre a luta pela intimidade e pela gratificação" (CATTRALL apud SOHN, 2002, p. 108).

Já Kristin Davis (Charlotte) afirma que o programa é sobre o movimento cultural de uma geração que cresceu tendo escolhas, podendo não casar em determinada idade se assim não quisesse e optar por seguir uma carreira profissional. Diferente das mães desta geração, as mulheres agora têm escolhas, logo, podem ter a vida que querem (apud SOHN, 2002).

O intuito de romper com alguns paradigmas da televisão, principalmente em relação ao sexo, era o própósito da sitcom (STAR, 2004). Darren Star sabia que a temática, vista pelo ângulo feminino, era importante no programa: "as pessoas não assistem STC para ficarem excitadas, mas porque é engraçado. Nós podemos fazer coisas diferentes e explícitas porque elas são engraçadas" (STAR apud SOHN, 2002, p. 36). Segundo o criador, um dos diferenciais é que as mulheres se vêem na tela da TV, passando por aquelas situações:

marido e filhos, ao que as amigas são contra (Ep.7, $4^{\mathrm{a}}$ temporada). Apesar de decidida, Charlotte se sente constrangida e pressionada, por isso tenta se justificar dizendo que também será voluntária em um programa de prevenção à AIDS. Em uma discussão com Miranda, reclama: "O movimento feminista fala sobre escolhas. Se eu quiser largar meu trabalho, essa é minha escolha". 
Eu acho que o programa empoderou muita gente. É muito mais fácil casar quando você sente que está de bem consigo mesma e sozinha. Quando se chega aos 30, você tem um senso de identidade e sabe que sua identidade não depende de outra pessoa ou do fato de ser ou não casada. (...) As mulheres do programa são como muitas mulheres de hoje que não sentem esta pressão para casar, elas estão focadas em suas carreiras. Então, as suas jornadas são muito mais sobre auto-conhecimento e empoderamento pessoal do que qualquer outra coisa. (...) Uma das grandes mensagens de STC é que não há problema em ser solteira. (STAR apud SOHN, 2002, p. 36)

Cindy Chupack, uma das principais roteiristas de STC, diz que ao entrar para a equipe tinha 32 anos, era solteira e sentia muito a pressão deste estigma em um mundo onde os seus amigos estavam todos casando e tendo filhos. Segundo ela, as pessoas assistiam STC toda semana por causa "da procura, da dor, da confusão e da amizade" (CHUPACK apud SOHN, 2002, p.38). Ao ver que STC estava na capa da revista Time sob o título Quem precisa de um marido?, ela confessa ter pensado que "o clima havia mudado para as solteiras e parte da responsabilidade disto foi de STC" (CHUPACK apud SOHN, 2002, p.38).

Em suma, do ponto de vista da produção, a intenção declarada era mudar o paradigma de que o sexo na TV é proibido e, simultaneamente, empoderar as mulheres, mostrar que elas têm - felizmente - a permissão para fazer sexo livremente, usufruir de seu corpo como bem entenderem e sentirem-se bem sozinhas, sem ter necessariamente um homem ao seu lado, sem o estigma do casamento.

Como McRobbie (2006) já apontava ao falar sobre as propagandas do Wonderbra, a mulher exposta à STC, é também fruto de uma educação na ironia e de uma alfabetização visual. A grande eficácia deste repertório, segundo a autora, é que ele reside na garantia de desencadear reações efusivas contra um regime tirânico de puritanismo feminista (MCROBBIE, 2006). O feminismo, como os próprios criadores e atrizes aqui colocaram - tendo sido apenas mencionado, e negativamente, por Parker, aliás, outra estratégia para o deixar à margem - só é levado em consideração para mostrar que estamos em um outro momento. O feminismo, para eles, é passado, não merece atenção. Distanciados do seu debate e cientes de sua negação, o pósfeminismo ${ }^{7}$ toma forma já na produção de STC que, de acordo com esta noção, se

\footnotetext{
7 Assumimos aqui a posição de Angela McRobbie sobre o pós-feminismo, que o coloca como um processo ativo pelo qual os ganhos feministas dos anos 70 e 80 estão enfraquecidos.
} 
torna um de seus representantes nos últimos anos. Afinal, segundo Darren Star, as mulheres de STC são como a maioria das mulheres de hoje que assistem ao programa: enquanto esperam pelo par ideal, não se sentem pressionadas a casar, mas a progredir em suas carreiras. A pergunta que inquieta é: será mesmo?

\section{O texto Sex and the City}

De acordo com Hall (2003), o texto é um fator delimitador da decodificação. É a partir dele que a codificação é efetivada e que preferências de leitura são apresentadas ao receptor. Os sentidos preferenciais do texto trazem as práticas e crenças que este objetiva apresentar que, quase sempre, é a ordem dominante institucionalizada.

A análise do texto STC foi feita a partir de três eixos que consideramos recorrentes no programa: Sexo, Comportamento e Consumismo. Optamos por circular entre estes tópicos por considerá-los essenciais para o entendimento do processo de reconfiguração, remodelagem e/ou reafirmação das identidades pessoais, neste caso específico, da identidade feminina, fazendo com que suas fãs legitimem ou rejeitem práticas sociais propostas pela sitcom.

Dado o fato que todos os episódios tematizam uma questão sexual e o sexo foi algo que os produtores do programa queriam ressaltar, como "Sexo" definimos as relações sexuais strictu senso. Estando visível, mencionado, ou apenas subentendido, este eixo nos possibilita analisar como as personagens lidam com o sexo, sua potencialidade ou falta. Como "Comportamento", entenda-se os valores que engendram atitudes, estando relacionado às condutas e posicionamentos das protagonistas diante de determinadas situações, excluídas aquelas que envolvem sexo, por já serem contempladas no eixo anterior. O último eixo, "Consumismo", deve ser entendido em seu cerne: como as protagonistas se relacionam com o ato de comprar/consumir.

Optamos, em virtude da extensão de episódios (94), por trabalhar com apenas um de cada temporada, além dos dois últimos episódios da sitcom, por estes trazerem o desfecho da trajetória das personagens. Como o Brasil foi um dos países mais mencionados em STC (juntamente com a França), selecionamos aqueles episódios que fazem menção, preferencialmente verbal, ao Brasil ou a brasileiros (as). 
Dizemos isto pelo fato de que o programa também fez menção ao Brasil, de forma não explícita, através da inserção de sua música como trilha sonora e do uso da moda de estilistas brasileiros. A moda brasileira, por exemplo, foi utilizada no figurino de alguns episódios da $4^{\mathrm{a}}$ e $6^{\mathrm{a}}$ temporadas (RIBEIRO, 2004). O mesmo tendo acontecido com a trilha sonora brasileira, que foi utilizada em episódios da $3^{\mathrm{a}}, 4^{\mathrm{a}}$ e $5^{\mathrm{a}}$ temporadas (RIBEIRO, 2004) .

Foram definidos, então, como corpus de pesquisa, oito (8) episódios: O poder do sexo feminino (Ep. 05, $1^{\mathrm{a}}$ temporada), A dor maravilhosa (Ep. 12, $2^{\mathrm{a}}$

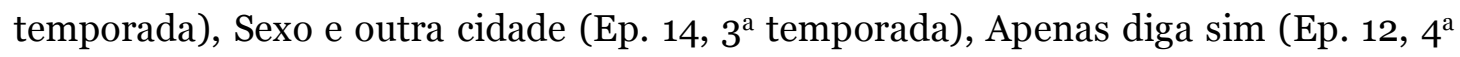
temporada), Pecado não original (Ep. 02, $5^{\text {a }}$ temporada), Luz, câmera, relacionamentos (Ep. 05, 6 ${ }^{\mathrm{a}}$ temporada), Uma garota americana em Paris - Part une (Ep. 19, 6 ${ }^{\mathrm{a}}$ temporada) e Uma garota americana em Paris - Part deux (Ep. 20, $6^{\mathrm{a}}$ temporada) ${ }^{9}$.

$\mathrm{Na}$ análise destes oito episódios, observamos que a mulher representada em STC pode tudo: compra o quer, faz sexo com quem deseja, alcança os objetivos profissionais que traça, freqüenta lugares concorridos e até mesmo supera decepções e doenças. A busca pelo prazer, assim como seu poder de compra, são uma espécie de resistência ao poder masculino, mas, por trás desta independência e despreendimento, a mulher tem medo de ficar sozinha.

STC explora a instabilidade feminina de duas maneiras: através dos sentimentos e da cultura de consumo. A troca de parceiros constante (Carrie, em cada temporada analisada está com um namorado, com exceção da quinta), a falta de uma referência familiar, a relação narcisística com seu corpo e com o universo de consumo mantém a mulher como objeto de uma cultura hegemônica onde o homem dá a última palavra e é só com ele que a realização é completa. Uma mulher pode optar

\footnotetext{
8 Utilizamos como referência o livro de Teté Ribeiro (2004) e a própria assistência da autora deste trabalho aos episódios para chegar a estes dados.

$9 \mathrm{Na}_{1}^{\mathrm{a}}, 2^{\mathrm{a}}, 3^{\mathrm{a}}$ e $6^{\mathrm{a}}$ temporadas, contabilizamos apenas um episódio que fazia menção verbal ao Brasil, sendo estes os selecionados destas temporadas. Na $4^{\mathrm{a}}$ temporada, tivemos quatro episódios onde houve menção verbal ao país 9 . Destes, foi selecionado aquele que melhor contemplava os três eixos de nossa análise: Sexo, Comportamento e Consumismo. A $5^{\text {a }}$ temporada foi a única que não apresentou nenhuma menção verbal ao Brasil, porém, três episódios continham música brasileira em sua trilha sonora. Entre estes, adotamos o mesmo critério de seleção da temporada anterior.
} 
por não ter filhos (Carrie/Samantha), por adotá-los (Charlotte), por tê-los sozinha (Miranda) mas, se um homem não estiver ao seu lado, nada disso terá valido a pena.

Apesar dos produtores do programa terem a intenção de exaltar a "solteirice", as sexualidades alternativas e a diversão da mulher atual, detectamos, em nossa leitura, traços do conservadorismo patriarcal. Três das amigas exercem profissões mais próximas do que, no senso comum, está relacionado ao feminino (Relações públicas, jornalista e marchand). Miranda é a única que é advogada, uma profissão que, no mundo televisivo, esteve sempre mais ligada ao masculino (COOPER, 2001). O homossexualismo (feminino e masculino) aparece com certa freqüência, mas cuidadosamente estabelece-se que a heterossexualidade é a melhor opção. O ponto de vista determinante é o feminino, mas o olhar masculino está sempre ali impresso. $\mathrm{O}$ feminino está sempre em função dele.

A mulher apresentada na tela é aparentemente desprovida de pudores sexuais, mas infeliz caso não tenha um laço afetivo. O diferencial de STC é que o casamento não é a única saída (apenas Charlotte e Miranda finalizam suas sagas românticas casadas), mas a união estável com um par é, sem dúvida, a melhor estratégia feminina para a felicidade. Mesmo ao trazer traços que o posicionariam como um programa feminista (a mulher independente, igualdade entre homem e mulher, sua posição favorável ao sexo sem compromisso, por exemplo) - , STC deixa implícito sua adesão ao "pós-feminismo" e à manutenção da submissão aos valores do patriarcado. A mulher, no programa, não está solteira por opção, mas pela falta de. Mesmo que muitas das oportunidades de sexo casual tenham sido por elas desfrutadas - principalmente por Samantha, adepta convicta do sexo sem compromisso até a quarta temporada - a possibilidade de um romance estava sempre à espreita. Quase todo homem em STC era visto com potencialidades para um compromisso, que eram derrubadas ou não por alguma exigência das amigas (como não suportar o sucesso da parceira, ter um pênis fora dos padrões, sofrer de déficit de atenção, beijar mal, ser "perfeito demais", etc.) ou até do parceiro (Miranda, em um dos episódios, convida um de seus pretendentes para subir até seu apartamento e este a rejeita por não ter se sentido atraído por ela). Mesmo ao consumir, o que seria uma decisão e ação solitária - e feminina -, na qual o homem não está incluído, a mulher depende da legitimação do parceiro. Carrie, em dois dos episódios analisados, 
deixa claro aos seus parceiros que gosta de roupas e sapatos caros, em outras palavras, que é uma mulher de gosto sofisticado e que se sente satisfeita em poder arcar com isto. A ele não compete julgá-la, apenas aceitar o fato e conviver bem com isto caso fique com ela.

Outro fator relevante em nossa análise é que não há uma referência familiar para as personagens. Nenhuma delas têm uma mãe presente, que dê conselhos ou indague quando chegarão os netos, por exemplo. A família, naquele ambiente, é representada pelas quatro amigas, uma dando apoio e aconselhando à outra, ou, vez que outra, pelos familiares de seus pares, como é o caso da mãe de Trey (primeiro marido de Charlotte), a mãe de Mr. Big (namorado de Carrie) e a mãe de Steve (namorado de Miranda). Neste aspecto fica transparente a relação da mulher solteira com a solidão, já que esta não tem vínculos familiares ${ }^{10}$. Estes vínculos, na sitcom, serão construídos pelo homem. Mas, enquanto elas não encontram o ideal, são as amigas que tentam suprir esta falta.

Em STC, os limites do que é ser homem e mulher não são bem claros. No episódio em que Carrie e Big brigam por ele não ter lhe contado que ia se mudar definitivamente para Paris (Ep.12, $2^{\mathrm{a}}$ temporada), torna-se evidente a posição de cada um no relacionamento: ele é o racional, ela a sentimental. No entanto, no penúltimo episódio do programa, é Big que questiona Carrie por ela não ter lhe contado antes que iria para Paris viver com seu atual namorado: ele passa então a ser o sentimental.

Consideramos que os paradoxos do programa se configuram como uma tentativa de empoderamento da mulher, exatamente como era a proposta de seu criador Darren Star: os assuntos dizem respeito ao feminino, as personagens são mulheres, o público-alvo são mulheres e muitas diretoras e roteiristas também eram do sexo feminino. Nos oito episódios analisados, por exemplo, cinco foram escritos e dois dirigidos por mulheres. Segundo Corinne Squire (1997), o termo “empoderamento” indica um interesse na evolução política, econômica e educacional

\footnotetext{
${ }^{10}$ A mãe de Miranda falece em um dos episódios (Ep.8, $4^{\mathrm{a}}$ temporada). As amigas vão à Filadélfia encontrá-la no enterro, mas sua inserção no programa se resume a isto. Em outro episódio (Ep. 17, $4^{\mathrm{a}}$ temporada), Carrie cogita que não tem boas relações com os homens devido à sua relação com o pai, que abandonou-a aos cinco anos de idade, mas depois disso não há nenhuma outra menção explícita à família.
} 
da mulher e também na sua própria consciência das escolhas individuais e sociais que estão ao seu dispor. João Freire Filho (2006) aponta que o conceito, em linhas gerais, diz respeito ao processo através do qual indivíduos ou grupos sociais passam a ter sua capacidade de decidir sobre suas vidas ampliada a partir de uma evolução na maneira como compreendem suas potencialidades e sua inserção na sociedade. $\mathrm{Ou}$ seja, STC empodera a mulher a partir do momento que expõe na tela opções que desestabilizam as representações que estão no consenso cultural, mas a aprisiona quando legitima estas mesmas representações ao se aproximar do desfecho do programa.

No último capítulo da sitcom, quando as quatro personagens têm seu "final feliz", aos moldes dos romances folhetinescos, é especialmente possível visualizarmos esta legitimação. As posições que as personagens colocaram em dúvida - e muitas vezes rejeitaram - durante o programa, foram as mesmas que as fizeram felizes em seu final. Samantha rejeitava o fato de ter um relacionamento estável, mas teve seu desfecho ao lado de Smith Jerrod, um jovem ator que a ajudou a superar seu câncer de mama. Miranda sempre se opôs ao fato de casar, diminuir sua carga horária no trabalho, ser uma dona-de-casa e morar no subúrbio com a sogra, mas assim o fez pela sua família. Charlotte sonhava com um "príncipe encantado", casar de branco na igreja e ter muitos filhos. Casou duas vezes, sendo a última com o advogado do seu divórcio, Harry, em uma sinagoga. Ele, por sua vez, tem alguns quilos a mais, é careca, tem problema de excesso de pêlos e sudorese. Para suprir seu lado maternal, Charlotte cria cachorros de raça enquanto aguarda por uma adoção. E, por fim, Carrie fica com Mr. Big que, mesmo depois de fazê-la sofrer durante as seis temporadas, parece ter mudado e assume com ela uma vida a dois.

Após esta análise, podemos dizer que a trajetória da sitcom nestes seis anos projeta uma outra possibilidade, faz pensar sobre uma nova condição da mulher contemporânea, mas acaba por encarcerá-la em um mesmo lugar, em um refluxo antifeminista (FALUDI, 2001) onde os avanços da mulher devem ser apenas decorativos, já que sua saída para a felicidade - e igualdade - está sempre dependente do homem. A mulher, segundo a proposta de STC, está independente e solteira aos 30 anos, casando-se (ou encontrando seu par ideal) cada vez mais tarde, depois de ter diversas experiências, com diferentes parceiros (as). Entretanto, sua 
independência e liberdade sexual de forma alguma afetou àquela necessidade de ter um lar, de estar segura em um núcleo familiar. O ponto de vista no produto midiático aqui analisado é o da mulher mas, mais do que construído em relação ao masculino, está em função dele. As contradições nos comportamentos das personagens - e talvez até mesmo o desfecho de cada uma - são frutos de suas significações ainda condicionadas a uma cultura patriarcal. Esta nova mulher tem a liberdade de procurar por sua felicidade, como foi o caso de Carrie, Samantha, Charlotte e Miranda, desde que nesta felicidade esteja implícita a condição de talvez um dia não mais ser solteira. A mulher de STC, ao contrário do que os produtores queriam passar, não está convicta de seu poder: ela sente solidão, demonstra instabilidade e se compara constantemente às "mulheres casadas". No caso desta nova mulher finalmente encontrar a felicidade, o que aparentemente aconteceu com as protagonistas, restará saber se ela, como as personagens, terá realmente a encontrado - em seu par - ou simplesmente se acomodado com a idéia de que esta, enfim, era a norma e, assim, conformado-se dentro das mesmas posições que a cultura patriarcal desde muito cedo a condicionou.

\section{A recepção de Sex and the City}

O momento da recepção (ou decodificação) tem, para Hall (2003), suas próprias condições de existência e é também fruto de uma construção. Se a codificação produz alguns parâmetros dentro dos quais as decodificações vão operar, é fato que alguma correspondência entre ambos deve estar impressa, do contrário não haveria uma troca comunicativa. $\mathrm{O}$ autor nos indica três posições hipotéticas a partir das quais a decodificação de um discurso televisivo pode ser construída: a posição hegemônica-dominante (a espectadora opera dentro do proposto pelo produtor, decodifica a mensagem de acordo com o esperado), o código negociado (a espectadora reconhece definições hegemônicas, mas se permite adaptá-las ao seu lugar, podendo ou não dar sua adesão) e o código de oposição (a espectadora se posiciona de modo totalmente contrário àquele do produtor, opondo-se à sua mensagem). Segundo Hall (2003), estas não são posições estáticas, mas posições entre as quais o receptor se desloca dependendo do que a mensagem codificada nele aciona. 
A pesquisa de recepção foi realizada com dezesseis (16) mulheres através de entrevistas em profundidade devidamente registradas em gravador. Em nosso recorte, esta audiência foi composta unicamente por mulheres que consideravam-se fãs do programa, residentes em Porto Alegre11 e indicadas, em um primeiro momento, por amigos, colegas e conhecidos do catálogo de endereços eletrônico da pesquisadora (rede de contatos) através do método que denominamos networking snowball (via e-mail), uma versão informatizada da tradicional "bola de neve". Além destas 12, entrevistamos mais uma fã de STC, Teté Ribeiro13, autora de um dos livros publicados sobre STC no Brasil. Devido ao fato da escritora e jornalista residir em Washinghton no momento da entrevista, esta foi a única entrevista não presencial, via e-mail, totalizando, então, dezessete (17) entrevistas que seguiam um roteiro básico, embora não se mantivessem a ele atrelado.

O que estas mulheres, todas brancas e de estrato médio14, entre 23 e 53 anos, nos informaram em relação aos três eixos que consideramos recorrentes em STC, foi que, em suma, elas só querem ser salvas. Salvas de um ambiente onde elas ainda são julgadas caso distanciem-se da norma, do lugar que é esperado delas. E isto pode ser visto especialmente no caso da "solteirice", tema que é carro chefe de STC.

Mais pontualmente, observamos que as fãs da sitcom em alguns momentos parecem resistir e em outros aderem às representações de feminilidade que STC prega. O bom-gosto ao vestir e a amizade entre aquelas mulheres, por exemplo, adquirem um grande valor para as entrevistadas, já que não vêem este laço como usual no mundo material. Ser feminina, em suas concepções, é ser também emocional, logo, o pragmatismo e a resistência ao envolvimento da personagem Miranda a coloca em uma posição de rejeição devido a sua não naturalidade. Já a personagem Samantha, apesar de admirada pela sua liberdade, é muitas vezes vista

\footnotetext{
${ }^{11}$ Apenas uma das indicadas morava em uma cidade da grande Porto Alegre. Como ela vinha sempre à Porto Alegre devido ao fato de seu namorado ser daqui, ela foi integrada à pesquisa. 12 Destas, cinco mulheres foram indicações das próprias entrevistadas que, após a entrevista forneceram o contato de suas amigas que também eram fãs do programa. 13 Teté Ribeiro, no momento da entrevista, residia em Washington, sendo esta a única entrevista realizada por e-mail, de 24/03/06 à 30/04/06. Neste período foram trocados nove (9) e-mails com a autora, entre o convite para participação e a efetiva resposta às questões formuladas pela pesquisadora.

14 Isto foi suposto pela pesquisadora a partir do nível de formação das entrevistadas (a maioria tem pós-graduação completo ou em curso), de suas condições de moradia (no caso das entrevistadas em suas casas) e de suas atividades profissionais.
} 
como promíscua pela sua quantidade de parceiros. No que diz respeito às representações da masculinidade, Mr. Big era a figura do sedutor, do poder e da virilidade em STC, qualidades por elas exaltadas em um homem. Embora admitam que o homem "ideal" esteja mais próximo de Aidan, com quem Carrie se recusou a casar, que era carinhoso, atencioso e fiel, as informantes "entendem" porque ela o dispensou. Ou seja, não há um parâmetro de comportamento masculino que garanta a satisfação destas fãs nem no plano simbólico, tampouco no material, tudo depende da variável naquele instante nelas aflorado, da posição de decodificação por elas assumida.

Ainda neste caminho, vemos que as entrevistadas têm suas identidades femininas reconfiguradas a partir do produto midiático, pois diversas delas relataram que o programa as fez tomar atitudes que antes não cogitavam, mesmo que estas “atitudes" estejam mais para o plano do pensamento do que propriamente da ação. Nenhuma delas mudou drasticamente seus posicionamentos. Nenhuma delas passou a praticar sexo sem compromisso como Samantha (até porque o eixo Sexo não teve tanta repercussão junto a elas), a comprar compulsivamente como Carrie (o eixo Consumismo também não obteve grande repercussão) ou a buscar um casamento a qualquer preço como Charlotte (Comportamento). No entanto, elas acreditam que o programa as empoderou quando, na verdade, apenas reafirmou suas identidades, principalmente enquanto solteiras: apesar do casamento não ser o maior objetivo, elas não querem ficar sozinhas, têm necessidade de ter um homem forte e decidido ao seu lado, de constituir uma família, de fazer parte do mundo de "casais felizes". Se a produção de STC prega a euforia e a diversão do ser solteira na contemporaneidade, o texto e as receptoras expõem muitos momentos de desamparo, conflitos e questionamentos em relação a isto. É verdade que as personagens de STC não perdem a oportunidade de lançar-se às novas possibilidades que se apresentam, mas acabam sempre recuando ao seu lugar de origem. Assim como Hall argumenta (2003), as informantes oscilam da posição hegemônica-dominante à negociada. Se em determinado instante elas se incomodam - ou se admiram - com a vida fácil daquelas mulheres bem-sucedidas, enquanto elas estão ainda na luta por uma melhor condição de trabalho -, em seguida já estão comemorando - ou achando "piegas" - o final romântico do programa. 
Notamos que STC não apenas estabelece com as entrevistadas o que Ang (1985) chamou de realismo emocional (que se refere a personificar as emoções das personagens), elas vão além, sendo sua principal relação com o programa a verossimilhança cultural (GLEDHILL, 1997). As mulheres reconheciam o seu cotidiano, viviam aquelas situações com as personagens, tinham uma segunda chance de experimentar e pensar - através da outra representada na tela - a respeito de suas angústias, seus medos, suas fraquezas e até mesmo suas alegrias, mas o cotidiano que ali estava exposto ainda é concordante com o que a cultura dominante acredita que é aceito e próprio para a condição da mulher atual: não há problema em ser solteira, feliz e independente, desde que isto seja só uma fase e se saiba que esta não é a norma. O grande avanço da mulher contemporânea é que ela não abre mão de ter uma carreira, mas sua maior conquista está ainda nas mãos masculinas, pois só com um homem ao lado a sua felicidade - e a dos outros ao seu redor - é completa.

\section{Apontamentos finais}

Ser mulher no século XXI é, definitivamente, muito diferente do que no século passado. Principalmente no caso de também ser solteira. As solteiras do pósfeminismo têm uma agenda movimentada, alguns flertes em vista, uma carreira a se dedicar, programas como STC para se inspirar e sempre um ombro amigo onde chorar. Mesmo tudo sendo tão diferente, questionamentos acerca de sua condição ainda incomodam. Ser solteira na contemporaneidade, diante de tantas mensagens contraditórias que a mídia oferece, é muito mais que um estado civil, é uma batalha a ser vencida a cada dia - mesmo que silenciosamente, afinal, "não há mais problema em ser solteira" (STAR apud SOHN, 2002, p.36).

Ao reproduzir mulheres mostrando seu corpo com orgulho, praticando sexo sem compromisso, pagando suas contas, tendo o livre arbítrio para escolher seus futuros, decidir entre casar ou morar junto, por exemplo, produtos culturais como STC sugerem que a igualdade entre homens e mulheres está alcançada, logo, não é mais necessário lutar por ela (MCROBBIE, 2006). As ações destas mulheres, filhas do pós-feminismo, são frutos de um querer consciente, não sendo elas mais exploradas, como poderiam pensar as feministas de outrora. A condição primeira 
para o pós-feminismo existir é assumir que o feminismo está ultrapassado e que a mulher de hoje está em outro patamar.

O que observamos aqui é que tanto no momento de sua produção, quanto em seu texto e em sua recepção, STC posiciona o feminismo no passado: a mulher a que ele é endereçado é inteligente o suficiente para entender todos os seus sentidos e saber que está em outro lugar, logo, o feminismo não faz mais parte de sua cartilha. Ou melhor, quando faz, é para ser repudiado. Quando Carrie se entrega a um francês no primeiro encontro, ela está fazendo algo permitido, de acordo com sua vontade, aquele é um ato de liberação, não de exploração. A mulher representada em STC é emancipada e dona de seu destino, mas não deixa de sofrer por isto. É o que pôde ser visualizado nesta dissertação tanto em seu texto, como também no momento da recepção: ser solteira aos 20 anos realmente não é problema, mas o mesmo não acontece acima dos 30 ou 40 anos. Não especificamente por causa delas mesmas, mas pela cobrança que sentem da sociedade para que se adequem, entrem na norma, façam parte do mundo de casais felizes. Neste contexto onde o feminismo só é lembrado para demonstrar o quanto está ultrapassado, as mulheres, amparadas pela esfera midiática, sentem-se aptas a (re) produzir o discurso de que podem tudo e sentem falta de quase nada. Isto é o que McRobbie (2006) chama de "duplo enredamento", ou seja, a co-existência de valores neo-conservadores em relação a gênero, sexualidade e vida familiar com fluxos de liberação em relação à escolha e à diversidade nas relações domésticas, sexuais e de parentesco, além da existência do feminismo como algo que foi em algum momento transformado em algo repudiado pelas mulheres (MCROBBIE, 2006). É esta contingência que dá o tom do pósfeminismo e, conseqüentemente, estabelece um novo regime de gênero a que programas como STC parecem tão bem servir de sinalizadores. 


\section{Referências}

AKASS, Kim; McCABE, Janet. (Org.) Reading Sex and the City. London: I.B. Tauris, 2004.

ANG, Ien. Watching Dallas: soap opera and melodramatic imagination. London/New York: Routledge, 1985.

CASEY, Bernadette et al. Television Studies: The Key Concepts. London/New York, 2002.

COOPER, Brenda. Unapologetic Woman, "Comic Men” and Feminine Spectatorship in David E. Kelley's Ally McBeal. Critical Studies in Media Communication, n.4, 2001. Disponível via compra de artigo em http://www.amazon.com. Acesso em: fev. 2006.

DOW, Bonnie. Prime-Time Feminism: Television, media culture, and the Women's Movement since 1970. Philadelphia: University of Pennsylvania Press, 1996.

EDWARDS, Tamala. M. Flying Solo. Time Magazine, New York, v. 9, n.156, p.3341, 28 ago. 2000.

FALUDI, Susan. Backlash: o contra-ataque na guerra não declarada contra as mulheres. Rio de Janeiro: Rocco, 2001.

FREIRE FILHO, João. Poder de Compra: Pós-feminismo e consumismo nas páginas da Revista Capricho. In: COMPÓS, 2006, Bauru. Anais eletrônicos.

GITTLIN, Todd. Estilos de navegação e espetáculos políticos secundários. In: Mídias sem limite. Rio de janeiro: Civilização Brasileira, 2003.

GLEDHILL, Christine. Genre and gender: the case of soap opera. In: Stuart Hall (Org). Representation: Cultural representations and signifying practices. London: Sage, 1997, p. 337-384.

HALL, Stuart. The work of representation. In: Stuart Hall (Org). Representation: Cultural representations and signifying practices. London: Sage, 1997, p. 1364.

. Codificação/Decodificação. In: SOVIK, Liv (Org.). Da

Diáspora: Identidades e Mediações Culturais. Belo Horizonte: UFMG, 2003c, p. 387-404.

JENKINS, Henry. Textual Poachers: television fans and participatory culture. London/New York: Routledge: 1992.

JOHNSON, Richard. O que é, afinal, estudos Culturais? In: SILVA, Tomaz Tadeu da (Org.) O que é, afinal, Estudos Culturais? Belo Horizonte: Autêntica, 2004, p.9-131.

MAGESTRE, PAULA. Mulher solteira procura: Por que mulheres bem-sucedidas e interessantes têm dificuldade em encontrar um companheiro para a vida. Revista Época, São Paulo, n. 250, p.50-57, 3 mar. 2003. 
MCROBBIE, Angela. Post-feminism and popular culture: Bridget Jones and the new gender regime. In: CURRAN, James; MORLEY, David. Media and Cultural Theory. London/New York: Routlege, 2006, p. 59-69.

SEKEFF, Gisela. Com diploma e sem marido. Veja Especial Mulher, n.65, jun. 2006, p.34-36.

SEX and the City. Direção: Darren Star e Michael Patrick King. HBO, 1998-2004. 6 DVD's (45 horas), cor.

SPANGLER, Lynn. Television Women from Lucy to Friends: fifty years of sitcoms and feminism. London: Praeger, 2003.

SQUIRE, Corinne. Empowering Women? The Oprah Winfrey Show. In: BRUNSDON, Charlotte; D'ACCI, Julie; SPIEGEL, Lynn (Org). Feminist Television Criticism: A Reader. Oxford: Clarendon Press, 1997, p. 98-113.

SOHN, Amy. Sex and the City Kiss and Tell. New York: Pocket Books, 2003.

STAR, Darren. How 'Sex' changed the face of TV. CNN.com, Washington, 22 fev. 2004. Disponível em: http://www.cnn.com/2004/SHOWBIZ/TV/02/21/cnna.darren.star/index.ht ml Acesso em: 23. dez. 2005.

THE WOMEN OF SEX AND THE CITY. The E! True Hollywood Story. São Paulo: E! Entertainment Television, 8 ago. 2006. PROGRAMA DE TV. 